\title{
Critical Evaluation of Continuous Improvement and Its Implementation in SMEs
}

Pritesh Ratilal Patel, Babaria Institute of Technology, India

https://orcid.org/0000-0002-7067-978X

Darshak A. Desai, G. H. Patel College of Engineering and Technology, India

\begin{abstract}
The purpose of this paper is to represent the current scenario of continuous improvement activities of SMEs in Indian context in different sectors. Literature study focuses on the approach of implementation of CI activities in SME, overseas, and Indian sub-continent based on the tools and techniques adopted. Continuous Improvement is an organisational innovation and design principles rooted in TQM paradigm in context with Indian SMEs. An increase in the number of SMEs in developing country like India give rise to a number of organizations to impart focus towards the emphasis on improvements, performances, cost reductions, benchmarked products, etc. to achieve competitive success and sustain in the present turbulent environment. SMEs significantly contribute to industrial and national economy to any developing country to be competitive in this era of international business. SMEs generally are observed with lack of financial resources, time, and efficient number of expertise, as advocated by number of authors.
\end{abstract}

\section{KEYWORDS}

Incremental Improvement, Industries, Innovations, Methodologies, Philosophies, Processes, Review, Techniques, Tools

\section{INTRODUCTION}

"Change is a requisite law of Universe". Change, in industrial context, large enterprise or small, may be in an individual, a group, culture, an enterprise etc. that leads to improvement activities. Synonymous to that, Kaizen is a Japanese word composed of two concepts: Kai (change) and Zen (for the better) (Palmer, 2001). Kaizen is defined as a Japanese philosophy of Continuous improvement, being globally used by organization with an objective a dynamic change for better. KAIZEN indicates a process of continuous incremental improvement of standard way of work (S. Lee et al, 2000). In western companies it is coined as Continuous Improvement (CI). Major companies around the world are encountering a necessity to provide a positive response to the changing circumstances, customer's requirements, desires and tastes. In order to compete in this continuous changing environment globally, the companies (large or small) needs to identify and develop new methods that promote them to remain competitive, flexible, qualitative, cost efficient, enabling their companies to respond rapidly to new demands. The phrase "CI" is associated with variety of organisational development techniques like 
Lean manufacturing, total quality management (TQM) employee improvement programmes, customer service initiatives and waste reduction campaigns.

In 1990s CI had emerged as one of the key issue in organisational design as well as quality management. (Choi, 1995). The philosophy of CI offer flexibility in adaption to the changing operational environment and adjacently improvise employee participation. CI systems are very complex, making it impossible to isolate the tools and techniques used to achieve quality and productivity objectives from the people engaged (Jurburg et al, 2016). There has been number of cases whereby the company has tried to imitate or transfer certain technique which have proved successful somewhere but failed because there was a failure to engage people inside the organisation (Jaca et al, 2014). CI has been always been a part of craftsmen, academics, professionals and managers, who are expected to develop their individual skill. This has relation that, although strongly associated to quality, CI as a concept has its roots in many other field, including, Socio-technical system design, human relation movements and more recently the discussion surrounding 'lean manufacturing. (Womack and Jones, 1997).

In the simplest form, CI can be defined as a company-wide process of focussed and continuous incremental innovation-small step, short cycles of change, which taken alone have little impact but in cumulative form can make a significant contribution to performance. (J. Bessant et al, 1994). The improvement not only the results a team but also the process itself (J. Bessant, 1998). Compared to other strategies of innovation, $\mathrm{CI}$ is a low cost investment but a much greater effort to learn innovation is required. The improvement activities as carried out are in incremental or gradual way rather than radical ones. A major improvement takes place with passage of time as a result of numerous incremental improvements. These changes are obtained with usage of tools and techniques that are dedicated to finding the sources of problems, waste, variation and finding the ways to minimise them (Nadia Bhuiyan, Amit Baghel, 2005).

\section{INNOVATION AND KAIZEN}

Innovation may be defined as a new function or improving the functionality of a product, process or service for a product that can respond to the market demand or generate a new demand from the market. It may also be defined as the activity that allows the apparition of innovation as a product and which is based on an individual, social, on a company, creative and dynamic behaviour.

Incremental innovation deals with processes of modification, simplification, refining, consolidation and improving of product or processes, the services and the activities of production and distribution already existing. On the other hand radical innovation implies the inserting new or services that are developing into a new business. It may result into creation of a new industry or can cause a major change in a whole industrial branch tending to new systems or values (Aurel Mihail Titu et al, 2015).

Radical innovation refers to product and processes those results from advances in knowledge whereas incremental innovation refers to the continual process of improvement of techniques (Mole and Elliot, 1987). Competitive pressures from world-wide operations provide strong motivation for innovation. According to Schonberger (1986), who popularised the term world-class, " Today there is wide agreement ... that continual improvement in quality, cost, lead time, and customer service is possible, realistic, and necessary'. Kaizen philosophy is better suited to a slowly growing economy while innovation is better suited to a fast growing economy (G. Wittenberg, 1994). Kaizen produces results through Process orientation (Ray Cheser and Cheryl Tanner, 1993). The broader comparison between Kaizen and Innovation is presents in Table 1. 
Table 1. Comparision of Kaizen and Innovation (Source: Karkoszka \& Honorowicz, 2009, Radharamanan, Godoy \& Watanabe, 1996 and J. Singh and H. Singh, 2019)

\begin{tabular}{|c|c|}
\hline KAIZEN & Innovation \\
\hline Creativity & Ability to adaptation \\
\hline Individualism & Teamwork \\
\hline Orientation towards the specialists & Orientation towards person having no specialized qualifications \\
\hline Attaching great value to the general matters & Attaching great value to the details \\
\hline Orientation towards techniques & Orientation towards human \\
\hline Information directed to the chosen persons & Free-for-all information, generalized \\
\hline Searching for the new technology & Basing on the existing technologies \\
\hline Limited feedback & Strong feedback \\
\hline Short-time effect & Long-time effect \\
\hline Participation of several chosen "leaders" & Participation of every worker \\
\hline Adaptation to the fast-growth-rate economy & Adaptation to the slow-growth-rate economy \\
\hline Big investment needed & Small investment needed \\
\hline $\begin{array}{l}\text { Results in the aspect of profit as the } \\
\text { estimation criterion }\end{array}$ & Processing estimation criterion \\
\hline Continuous and incremental & Intermittent and not incremental \\
\hline Collective team efforts, system focus & Strong individuality, individual ideas, and efforts \\
\hline Maintenance and improvement & Rejection and rework \\
\hline Know-how and conventional updating & Technological advances, new inventions, and new theories \\
\hline Persons & Technology \\
\hline $\begin{array}{l}\text { Demand less investment; however, greater effort to } \\
\text { maintain }\end{array}$ & Demand large investment; however, less effort to maintain \\
\hline
\end{tabular}

\section{WHAT IS KAIZEN?}

The literature review carried out using Kaizen as a term search revealed that Kaizen appears to refer to two kinds of papers. One kind researched the Japanese variant of Kaizen, as defined by Imai, 1986, while the other looked at the Western interpretation of Kaizen as CI (Continuous Improvement).

\section{Japanese Theme of Kaizen}

The Japanese concept of Kaizen (Continuous Improvement) integrates both scientific and humanistic management philosophies. It is the primary process that leads to continual improvement of the quality of life of all individuals associated, by focussing on areas such as recognition, training and the development of individual; innovation and outcome become natural and expected product of the process. Various definitions of Kaizen as depicted by different authors is as presented in Table 2

\section{The Western Theme of Kaizen}

The term commonly used in literature to refer to the western theme of Kaizen is Continuous Improvement (CI). CI is defined in different ways as depicted in Table 3

Mary Walton (1986) has described Kaizen strategy depends mainly on human efforts to improve results requiring process improvement. The origin of process-improvement approach PDCA or Deming cycle can be tracked back to the work of eminent statics expert Walter A. Shewart (concept of plan, 
Table 2. Definition of kaizen

\begin{tabular}{|c|c|}
\hline Author & Definition of Kaizen \\
\hline Hyland et al., 1998 & $\begin{array}{l}\text { Teamwork, empowerment and training are key elements of kaizen and these concepts } \\
\text { can aid in the change process }\end{array}$ \\
\hline McAdam et al., 2000 & $\begin{array}{l}\text { Kaizen creates a culture that allows employee creativity and ideas to flourish, the } \\
\text { result is that SMEs will be able to react quickly to change and react better or differently } \\
\text { across major company functions }\end{array}$ \\
\hline $\begin{array}{l}\text { Sameer Kumar and Harms, } \\
2004\end{array}$ & $\begin{array}{l}\text { Kaizen is never ending process and the one that puts emphasis on communication and } \\
\text { trust between workers and management }\end{array}$ \\
\hline $\begin{array}{l}\text { Gondhalekar et al., } 1995 \\
\text { Zulfiqar Khan and Rajeev K. } \\
\text { Bali, } 2007\end{array}$ & $\begin{array}{l}\text { These views are in agreement with the Japanese view of kaizen where it is viewed as } \\
\text { an umbrella concept with different methodologies, such as TQM represented within it. } \\
\text { Kaizen does offer the potential to launch a company transformation towards TQM by } \\
\text { aligning the employee's and management's goals }\end{array}$ \\
\hline Aoki, 2008 & $\begin{array}{l}\text { It is feasible to trade-off or transfer Kaizen to other countries where the culture } \\
\text { is different to that of Japan, provided that they succeed in implementing in these } \\
\text { organisation -outside of Japan- Kaizen's fundamental capabilities (basic principles) } \\
\text { which from the view point of author are: employee based improvement seeking } \\
\text { initiatives, inter-departmental and functional communication, discipline of employees } \\
\text { and standardisation of work in order to eliminate "Muda" }\end{array}$ \\
\hline Farris et al, 2008 & $\begin{array}{l}\text { A Kaizen event is "focused and structured continuous improvement project using a } \\
\text { dedicated cross-functional team to address a target work area and achieve specific goals } \\
\text { in an accelerated time frame" }\end{array}$ \\
\hline $\begin{array}{l}\text { Suárez-Barraza and Tony } \\
\text { Lingham, } 2008\end{array}$ & $\begin{array}{l}\text { Kaizen can be viewed as a set of managerial principles that manage improvement and } \\
\text { learning. Kaizen is the Japanese word for 'Continuous improvement' or 'change for the } \\
\text { best'. }\end{array}$ \\
\hline Hassan Abdulmouti, 2015 & $\begin{array}{l}\text { Kaizen is the Japanese word for 'Continuous improvement' or 'change for the best'. } \\
\text { It refers to the philosophy or practices that focus upon continuous improvement of } \\
\text { processes in manufacturing, engineering and business management for various types of } \\
\text { organisations }\end{array}$ \\
\hline J. Singh and H. Singh, 2019 & $\begin{array}{l}\text { Originally a Buddhist term, Kaizen came from the words, "Renew the heart and make } \\
\text { it good". Therefore the adaption of Kaizen concept also requires change in the "the } \\
\text { heart of business," corporate culture and since Kaizen enables companies to translate } \\
\text { the corporate vision in every expect of company's operational practice }\end{array}$ \\
\hline
\end{tabular}

do, see) in the 1920's. The late TQM Guru Edward Deming modified this Shewart cycle as plan, do, check, act (PDCA) a continuous quality improvement cycle, containing four repetitive steps for CI and learning. This cycle is frequently connected to the Deming circle, defining $\mathrm{CI}$ in four never-ending phases Plan-Do Check-Act (PDCA). These concepts form the basis of the cycle:

- Plan- Study of the current situation, analyse and predict changes of improvement.

- Do- Execution of pilot measures on trial basis in a controlled circumstances

- Check- Eliminate the effect of changes to see if the desired result is achieved.

- $\quad$ Act- Steps carried out to standardise on a permanent basis.

The main purpose of this cycle is to iron out the abnormalities in the resulting work process and bring it back to harmony before moving to a new improving cycle. In other terms, the standardizing cycle maintain current work process, while the improving cycle improves them. These two cyclesPDCA and SDCA revolve regularly to spread a culture of CI as a standard practice within an organisation as shown in Figure 1. This means that an organisation shall never rest on present status quo condition. 
Table 3. Definition of continuous improvement

\begin{tabular}{|c|c|}
\hline Author & Definition of CI \\
\hline J. Bessant et al, 1994 & $\begin{array}{l}\text { CI involves a company-wide process of enabling a continuing stream of focused } \\
\text { incremental innovation }\end{array}$ \\
\hline $\begin{array}{l}\text { John Bessant and Sarah } \\
\text { Caffyn, } 1997\end{array}$ & $\begin{array}{l}\text { Continuous improvement (CI) is a widely used phrase that takes a variety of meaning. } \\
\text { For many people it resembles 'innovation' the continual quest to make things better in } \\
\text { products, process, customer services etc. with regards to quality, productivity, cost and } \\
\text { flexibility. For others it is a core value that lies at the heart of organisational renewal } \\
\text { programmes such as Total Quality Management. For others it means preoccupation with } \\
\text { relation to carry out waste reduction and quality improvement }\end{array}$ \\
\hline Boer et al, 2000* & $\begin{array}{l}\text { Continuous Improvement }(\mathrm{CI}) \text { is both a philosophy of change that involves seeing } \\
\text { opportunities for improvement in all work processes and a method for implementing } \\
\text { change that is characterized by company-wide involvement and incremental improvements } \\
\text { of existing processes }\end{array}$ \\
\hline T. Juergensen, 2000 & $\begin{array}{l}\text { Continuous improvement }(\mathrm{CI}) \text { is a philosophy that Deming described simply as consisting } \\
\text { of "Improvement initiatives that increase successes and reduce failures" }\end{array}$ \\
\hline $\begin{array}{l}\text { J. Bessant et al, 2001, } \\
\text { Mariana Corso et al } \\
(2007) \text {, }\end{array}$ & $\begin{array}{l}\text { Several authors have worked on understanding the CI process and how it can be } \\
\text { successfully managed through a set of enabling factors }\end{array}$ \\
\hline Marc Antoni et al, 2004 & $\begin{array}{l}\text { A purposeful systematic approach carried to facilitate knowledge sharing across projects to } \\
\text { obtain systematic and cumulative improvement in process and its derivatives. }\end{array}$ \\
\hline $\begin{array}{l}\text { Harry Boer and Frank } \\
\text { Gertsen, } 2003\end{array}$ & $\begin{array}{l}\text { An ability to combine operation effectiveness and strategic flexibility i.e. exploitation and } \\
\text { exploration }\end{array}$ \\
\hline $\begin{array}{l}\text { N. Bhuiyan and Baghel, } \\
2005\end{array}$ & $\begin{array}{l}\text { A culture of sustained improvement that targets elimination of waste organisational } \\
\text { systems and processes with involvement of organisation participants with low capital } \\
\text { investment. }\end{array}$ \\
\hline $\begin{array}{l}\text { N. Bhuiyan and Baghel, } \\
2005\end{array}$ & $\begin{array}{l}\text { A culture of sustained improvement that targets elimination of waste organisational } \\
\text { systems and processes with involvement of organisation participants with low capital } \\
\text { investment. }\end{array}$ \\
\hline Jorgersen et al, 2006 & $\begin{array}{l}\text { Based on Scientific Management, improved under the heading Industrial Engineering, } \\
\text { exported to and perfected in Japan in the form of Kaizen, CI has found its way to industry } \\
\text { worldwide and is currently regarded as one of the cornerstones of good management }\end{array}$ \\
\hline $\begin{array}{l}\text { Lidia Sanchez \& Beatriz } \\
\text { Blanco, } 2014\end{array}$ & A continuous process of improvement carried out with participation of all staff. \\
\hline Jurburg et al, 2015 & $\begin{array}{l}\text { The inter-related group of planned, organised and systematic processes of constant change } \\
\text { across the whole organisation, focused on engaging everyone inside the organisation into } \\
\text { achieving greater business productivity, quality, safety, ergonomics and competitiveness }\end{array}$ \\
\hline Singh and Singh, 2015 & $\begin{array}{l}\text { A culture of sustained improvement aimed at eliminating waste in all organizational } \\
\text { systems and processes, involving all organizational participants }\end{array}$ \\
\hline $\begin{array}{l}\text { Chartered Quality } \\
\text { institute, former Institute } \\
\text { of Quality Assurance }\end{array}$ & $\begin{array}{l}\text { "...a type of change that is focused on increasing the effectiveness and/or efficiency of } \\
\text { an organization to fulfil its policy and objectives. It is not limited to quality initiatives. } \\
\text { Improvement in business strategy, business results and customer, employee and supplier } \\
\text { relationships can be subject to continual improvement. Put simply, it means getting better } \\
\text { all the time" }\end{array}$ \\
\hline
\end{tabular}

Imai (1986, 1990), known as the father of CI introduced the use of Kaizen or CI as a philosophy for process improvement to the west in the book "Kaizen: The key to Japan's success". According to Imai there are three basic principles of Kaizen 


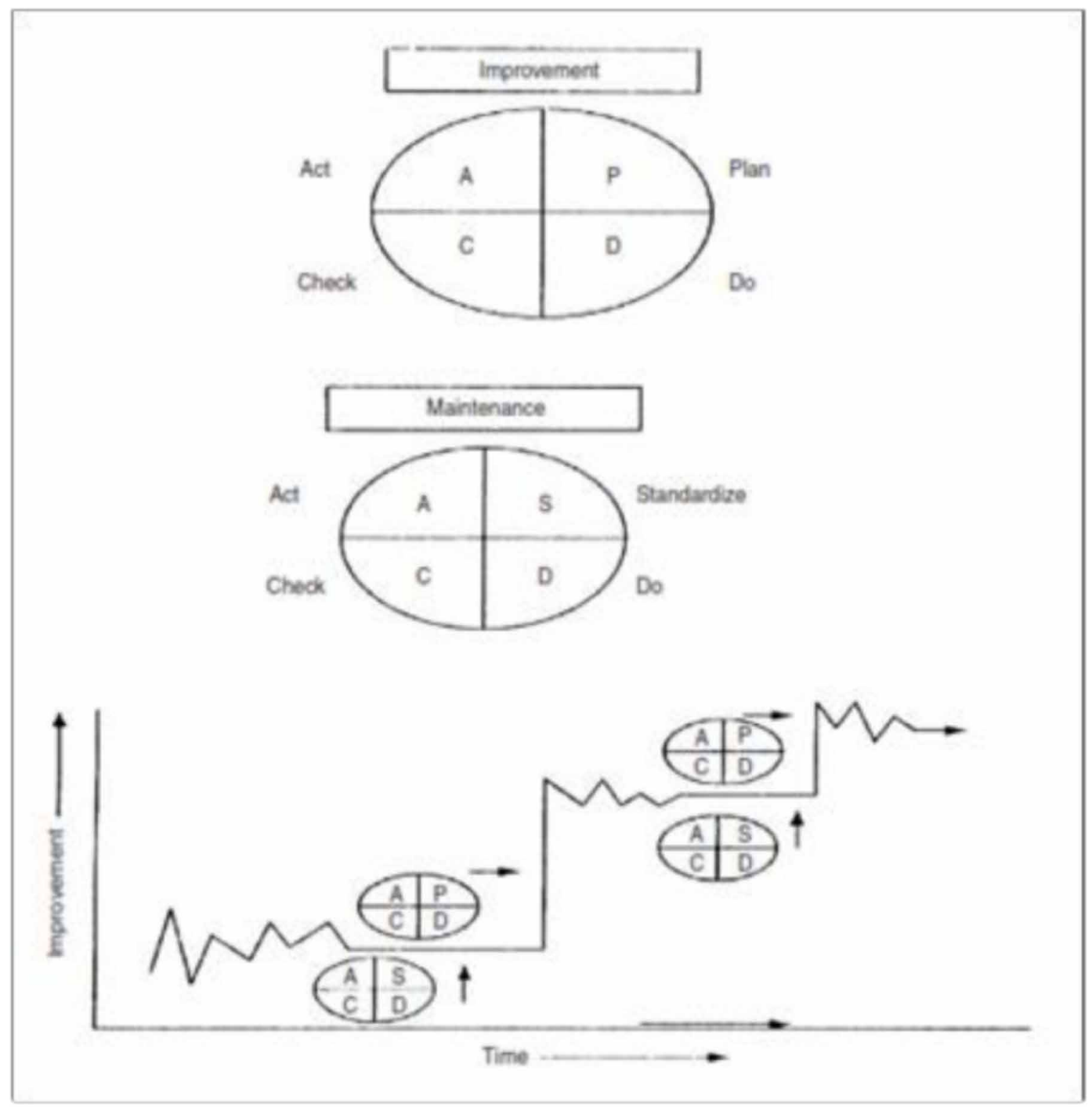

Principle 1: Kaizen is process-oriented, i.e. before results can be improved, processes must be improved, as opposed to result-orientation where outcomes are all that counts (Focus of management's attention needs to be directed towards creating sound processes).

Principle 2: Lasting improvements can only be achieved if innovations are combined with an ongoing effort to maintain and improve standard performance levels (maintaining standard operating procedures (SOP's) for all major operations).

Principle 3: Kaizen is people-oriented and should involve everyone in the organization from top management to workers at the shop floor. Furthermore, Kaizen is based on a belief in people's inherent desire for quality and worth, and management has to believe that it is going to "pay" in the long run. (In concern with the gradual improvement of systems procedures such as planning and control, organization, decision making processes and information systems but also to some extent the improvement of machinery and equipment). The relationship between Kaizen and CI 
also must be researched more to establish the similarities and/or the differences between the two concepts. (Daniel Carnerud et al, 2018)

Imai $(1986,1989)$ indicates Kaizen can take at least three forms:

1. Kaizen Management: The most important one and dealing with organisational strategy (policy and objectives) and management system that includes all company staff.

2. Group Kaizen: Focus on improvement of team and /or quality circles and solution of daily problems.

3. Individual Kaizen: Focus on bottom-up organisational design, i.e. staff suggestions from shop floor workers. These people are the ones who know work process best and are thus well placed to come up with solutions to problems.

Imai $(1986,1997)$ provides a set of concepts and features for implementing Kaizen:

- Kaizen and management, the responsibility of innovation and improvement remains with senior management whereas keeping of work standards and ensuring incremental improvements lies with middle managers and workers. In "Kaizen flag", Imai (1989) has shown that radical improvement responsibilities remains with top managers, operational movements work lies with middle managers and maintenance of process standards rests finally with the supervisors and operators (workers).

- The focus on processes versus results obtained.

- Continuous monitoring of PDCA to SDCA cycles by all company players.

- Rewarding quality

- Let the figure do something (statistical control)

- Customers constitute the next processes. follows:

In this connection, Berger (1997) proposed his own classification of Kaizen related teams as

1. Quality control circles: A group of people in the staff that meets regularly to discuss problems and issues related to quality and examine them and come up with solutions.

2. Wide-focus CI: A blend of organic CI and expert task force CI (as mentioned below) and used for temporary operations and for $\mathrm{CI}$ in self-managed work groups by combining continuous improvement process teams.

3. Organic CI: Multifunctional work groups are integrated with improvement activities. Organic $\mathrm{CI}$ is different from other CI models since the improvement activities are not left to the experts for design and planning and the decision-making is not left to the authorities outside the group.

4. Expert task force CI: This form of $\mathrm{CI}$ is based on the reliance on temporary expert task force consisting of professional from different departments like quality, engineering and maintenance and therefore the span of improvement tasks requires considerable time and investment.

5. Individual CI: Improvements are set off by individuals and generally organized in the form of a suggestion system. Individuals come up with ideas and the implementation of the ideas is left to the specialists.

\section{WHAT IS SMES?}

The Ministry of Small Scale Industries, Govt. of India, vide its notification number S.O. 1722(E), dated October 5, 2006, and has defined MSME based only on the criteria of their 'Investment in 
Table 4. Classification of an enterprise. Source: Ministry of MSMEs Annual report, 2017-18.

\begin{tabular}{|l|l|}
\hline Manufacturing Sector & Investment in plant and machinery \\
\hline Enterprise category & Does not exceed twenty five lakh rupees \\
\hline Micro enterprise & $\begin{array}{l}\text { More than twenty five lakhs but does not exceed five crore } \\
\text { rupees }\end{array}$ \\
\hline Small enterprise & More than five crores but not exceed ten crore rupees \\
\hline Medium enterprise & \multicolumn{2}{|l|}{} \\
\hline Service sectors & Does not exceed ten lakh rupees \\
\hline Micro enterprise & More than ten lakhs but does not exceed two crore rupees \\
\hline Small enterprise & More than two crore but does not exceed five crore rupees \\
\hline Medium enterprise & \multicolumn{2}{|l}{} \\
\hline
\end{tabular}

Plant and Machinery' in INR (Rs.). Refer Table 4 for classification of SMEs in Indian context in manufacturing and service sectors

The definition of SME differs from country to country. Comparative study of SMEs in different countries is as shown in Table 5. SMEs are defined specifically in terms of employment, investment or sales turnover or a combination of all of them in different countries across the globe (M. H. Bala Subrahmanya, 2009) or based on policies, economic conditions and industrial growth of the country (Majumdar, Manohar, 2016).

SMEs are being increasingly recognised as "the life blood of modern economies". These organisation require to remain competitive at both micro and macro levels. But non-availability of highly skilled labour at affordable cost, absence of adequate knowledge, technology, low production capacity, ineffective marketing strategy, (MSME annual report, 2018) constraints on modernisation and expansion, identification of new markets, follow-ups with various governmental agencies to resolve problems increasing exports, enhanced competition for suppliers and few low cost centres of production are the different challenges that the Indian SMEs are facing. Indian SMEs have been facing tough times due to globalisation and liberalisation of trade, coupled with World Trade organisation regime,

Table 5. Comparative criteria of SMEs in different countries Source: J.P. Majumdar, M. Manohar, 2016

\begin{tabular}{|c|c|c|c|c|c|}
\hline \multirow[t]{2}{*}{ Enterprise } & \multicolumn{2}{|c|}{ No. of employees } & \multirow{2}{*}{$\begin{array}{c}\begin{array}{c}\text { Investment in plant } \\
\text { and Machinery } \\
\text { (in Rs) }\end{array} \\
\text { India }\end{array}$} & \multirow{2}{*}{$\begin{array}{c}\text { Annual } \\
\text { Turnover (in } € \text { ) } \\
\text { Europe }\end{array}$} & \multirow{2}{*}{$\begin{array}{c}\begin{array}{c}\text { Balance sheet } \\
\text { total (in } € \text { ) }\end{array} \\
\text { Europe }\end{array}$} \\
\hline & Europe & Canada & & & \\
\hline Medium & $50-250$ & & & 10-50 million & 10-43 million \\
\hline - Manufacturing & - & $100-500$ & 5 crore -10 crore & & \\
\hline - Service & & & 2 Crore-5 Crore & & \\
\hline Small & $10-50$ & & & 2-10 million & 2-10 million \\
\hline - Manufacturing & & $5-100$ & 25 Lakh-5 Crore & & \\
\hline - Service & & $5-50$ & 10 Lakh-2 Crore & & \\
\hline Micro & $<10$ & $<5$ & & $\leq 2$ million & $\leq 2$ million \\
\hline - Manufacturing & & & Up to $25 \mathrm{Lakh}$ & & \\
\hline - Service & & & Up to $10 \mathrm{Lakh}$ & & \\
\hline
\end{tabular}


but the SMEs which have strong technological base, international business outlook, competitive spirit, willingness to restructure them and better withstanding to present challenges can contribute to Indian economy. The major economic reforms in India were introduced in 1991 and thereafter SMEs have been providing employment around 80 percent of the total people working in manufacturing sector.

\section{LITERATURE REVIEW}

Systematic review has been developed so as to provide a robust evidence based research. The literature review has been carried out in a structured way. The aim of the review has been to capture a picture of diverse facts in the field of Continuous improvement implemented in various organisations (excluding service sector). For the same purpose literatures published in peer reviewed journals containing words like "Kaizen" or "continuous improvement" in the title and keywords are reviewed. The editorials, news reports, book reports, masters and doctoral dissertations, textbooks and unpublished working papers are excluded. The literature review covers journal articles from 1985 to 2018. Major part of the focus has been on Kaizen and Continuous improvement in manufacturing both theoretical and case studies has been taken into consideration there-off. Peer reviewed Journal's database has been selected and designed to deliver a comprehensive bibliography for the described topic. The included journals from publishers like Emerald, Science Direct, Inderscience, Taylor and Francis, Routledge, IEE; Wiley publication etc. has been covered. There are 92 research papers taken for critical review and analysis for understanding the theoretical concept, implementation and importance of Continuous improvement in SMEs.

The research steps included comprise of the following: Literature search for understanding the basic concept of CI, formation of classification framework, Case study related articles for benefits of CI implementation, analysing the literatures studied, study of embedded technologies and philosophies with CI, identification of gaps and suggestions for future research. Figure 2 represents the research methodology adopted for this study.

\section{CLASSIFICATION FRAMEWORK}

Research Framework has been diversified into following aspects. The articles reviewed, analysed and classified on the basis of following dimensions:

\section{Articles Distribution Based on Year of Publication}

Figure 3 shows the distribution of 90 articles published on CI or Kaizen over a period of last three decades from 1993 to 2018. An average of 4 articles per year has been taken for study. Review considers CI related articles of theoretical interpretation, conceptual data, case studies and articles related to embedded philosophies and methodologies. Statistics has shown a decline from 20052006, whereas in last decade i.e., from 2008 to 2018, publication rate has been in increasing pattern as shown in Figure 3.

\section{Distribution by Publication Database}

Most of the papers related to theoretical interpretation of Kaizen or CI has been achieved from publishers like Emerald, Inderscience, Elsevier (Science direct), Taylor and Francis, Routledge, IEE, Wiley online library, Springer etc. The percentage contribution of papers under study is around $48 \%$ of Emerald, followed by Inderscience 14\%, Elsevier, Taylor and Francis: Routledge 9\%, IEE, Wiley and Springer 2\%.and so on. As a least contribution are Springer, Sage, Wiley and OCSCO with a combined contribution of around 6.5\% as shown in Figure 4. 
Literature search with the text "Continuous improvement" or :Kaizen" from peer reviewed reputed journals

Collection of articles with "Continuous Improvement" or "Kaizen" in title or keywords and Literature

$\downarrow \downarrow$

Inclusion of only journals, IEEE conferences (excluding book chapters, conference reviews, editorial notes, short surveys etc.)

Including Papers in English Literature only

$\downarrow$

Collected articles from Emerald, Inderscience, Science direct (Elsevier), Taylor and Francis, Wiley publication, Springer link, IEEE conferences etc.

Segregation of articles related to Literature on CI, implementation, case studies, perceived benefits and embedded methodologies.

$\downarrow$

Final review to 90 shortlisted Continuous improvement or Kaizen articles

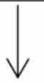

Classification of the shortlisted articles based on year of distribution, Publisher wise, continent wise and tools, techniques and methodologies of CI.<smiles>C1CC1</smiles>

Identification of Gap and suggestion for future work based on the observations and results

\section{Distribution of Articles Based on Continents}

The research articles related to of Continuous Improvement or Kaizen implementation and usage of related techniques and philosophies is highest in European countries (44\% out of 92 articles), followed by Asia (29.34\%out of 92 articles) and USA including North and South America (21.3\% out of 92 articles). Research shows that there has been least work in African and Australian continent as shown in Figure 5.

\section{Methodologies Applied in Research Work}

The Review of Literature depicts the usage of various tools, techniques and philosophies that are or can be used to attain CI or Kaizen. The review states that TQM and Lean are the widely used philosophies and philosophies used for CI followed by Benchmarking, CI implementation, Six Sigma and others. The usage of different tools, techniques and philosophy also depends on the industrial region or area. Figure 6. show several methodologies be used to attain Continuous Improvement. 


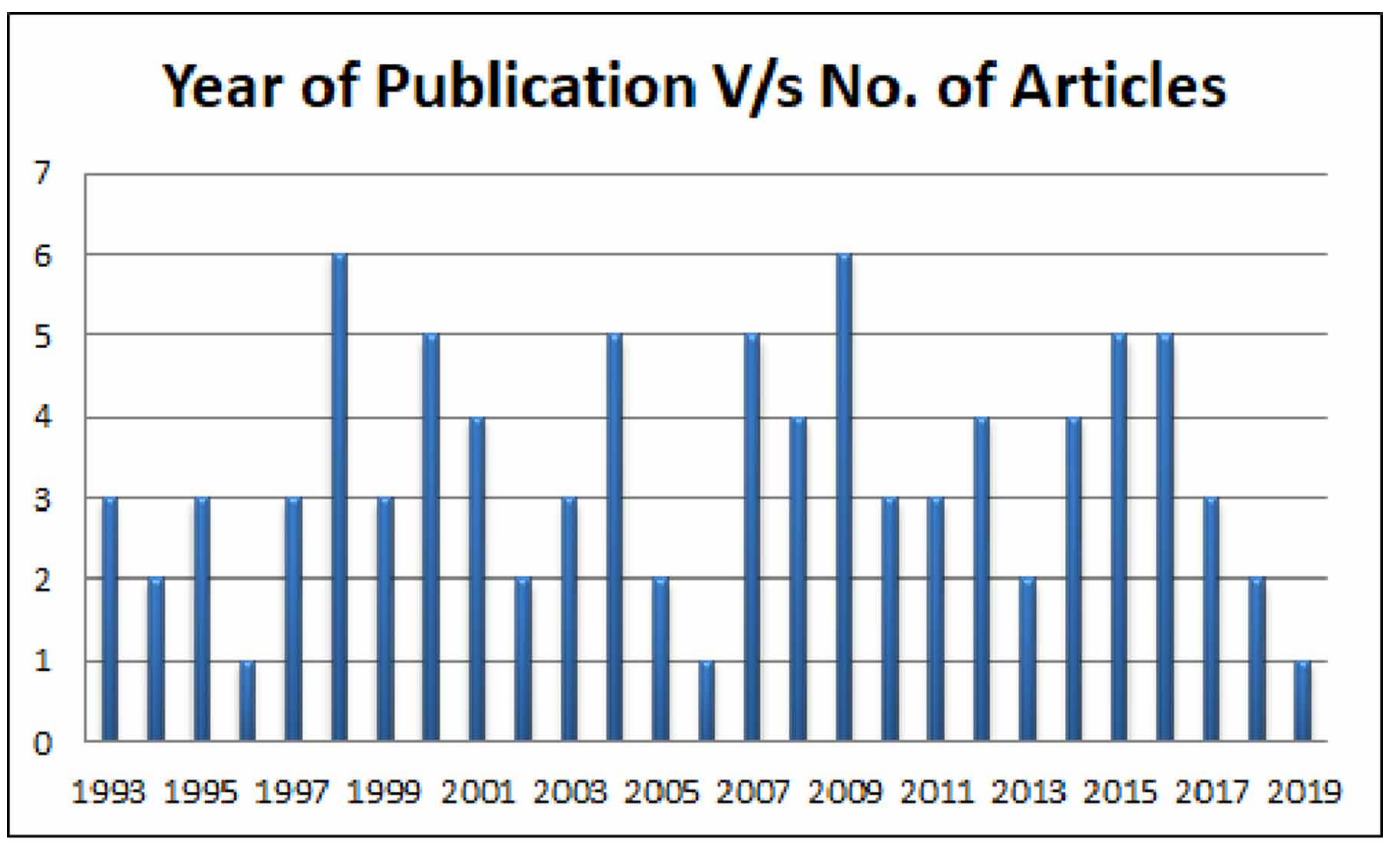

Figure 4. Publishers vs. number of publications

\section{Publishers v/s No. of Publication}

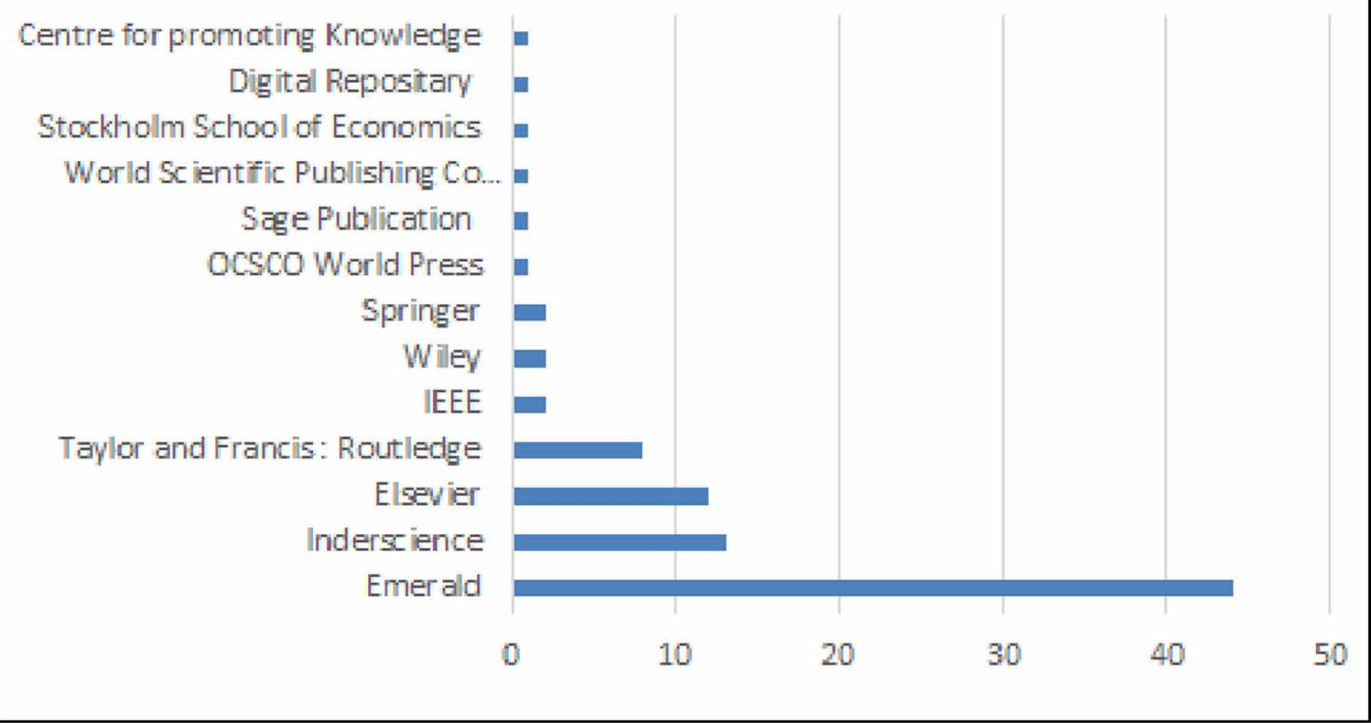




\section{Continent v/s Count}

Australia Asia - Europe USA - South Africa

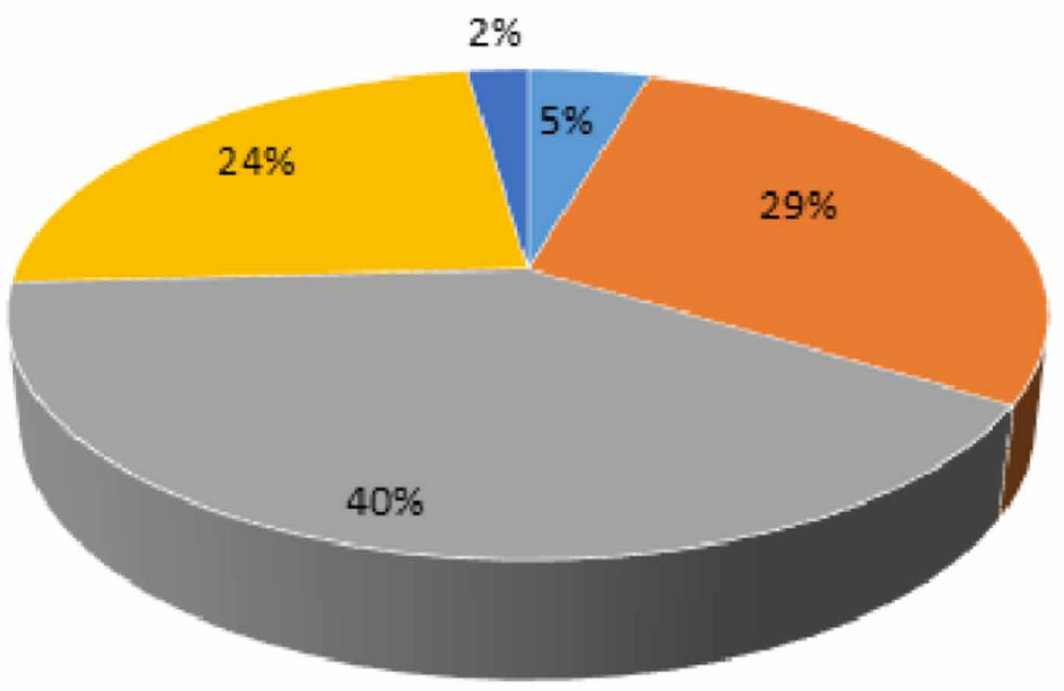

\section{LITERATURE STUDY FOR LEARNING CONTINUOUS IMPROVEMENT}

Change requires Learning. It is something of a cliché to talk of CI as 'a journey, not a destination'. A useful analogy can be made with learning to drive a car. In the early stages the problem is one of unfamiliarity with the whole experience. Learning is concentrated on trying to understand and master the individual low-level skills associated with things such as steering, the clutch, the brakes, and the accelerator and so on. Gradually, facility with these is developed, but then the challenge comes in linking the individual behaviours together in complex sequences: for example, changing gear or making a hill start. Eventually and after extensive trial and error and practice, the point is reached where you qualify for a driving licence. All this indicates, however, is an expression of basic competence. The real challenges of becoming a good driver, able to cope with different cars, weather conditions, different types of road, etc., still lie ahead (J. Bessant and S. Caffyn, 1997). A commitment to learning on the part of organisation is required for Continuous improvement (Edwin Locke and Vinod Jain, 1995).

\section{Literature Related to Theoretical Concept of Kaizen or $\mathbf{C l}$}

John Bessant et al, 1994 describes case studies about four different firms, mid-size engineering firm, a food and drink sector, Medium size electrical industry and a construction factory about organising CI activities that promoted the organizational employee move towards individual, self-directed and self-motivated activities, participation in team based problem solving, emphasis on the need of 


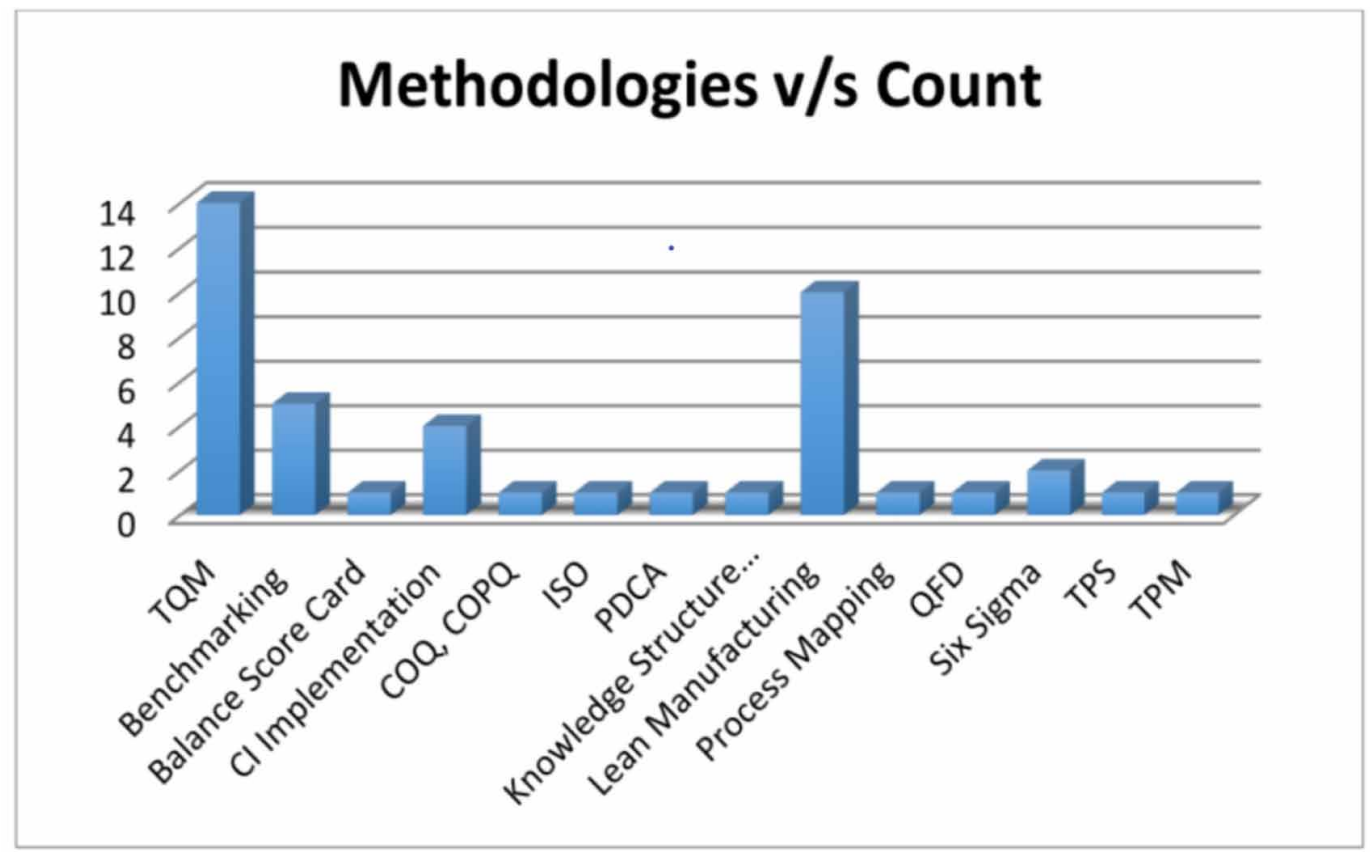

training an education, upgrading of skills, awareness of the tools in respective areas, etc., an essence of a cultural change throughout the organisation

G. Wittenberg, 1994, discussed about application of Kaizen strategy to manufacturing demonstrated at a "workshop event" run by the Kaizen Institute of Europe in 1993. The major improvement achieved were reduction of space, change in floor layout to accommodate new structures, division of assembling operation in sub assembling components for operators to work separately and improvement I flow of material and operator movement.

Shrinivas Gondhalekar et al, 1995 have presented an outcome of innovative experimentation carried out at Godrej Soaps limited of initiating TQM through implementation of Kaizen, companywide continuous improvement process. Results highlighted that Kaizen and more generally, TQM process and cannot be left on it after launching and regular intervention is required. Secondly, focussing of HR Department in a new direction leading to emphasis on lifelong education, reading, imparting creativity and communication in every individual.

J. Bessant et al, 2001, has presented five stages in evolution of CI practise in organisation. The first stage (Pre-CI) occurs once the organisation introduces the concept of CI without any effect on organisational performance. In the fifth stage (Overall CI), the whole organisation is involved in carrying out improvement activities of incremental and radical innovations. At this level, sharing of experience and knowledge takes place making it a model of organisational learning.

Brunet and New, 2003 discusses about the visit in 1998 at selected Japanese companies of Steel and automotive sectors to study about kaizen activities. The observation reveals kaizen programs aims not just achieving ad hoc improvements to operations, but assures the achievements in a target oriented planning system. In most cases the teams were themselves involved in setting their targets and management stressed the importance to make the targets achievable.

Zengin, 2010 highlighted that Kaizen costing concept, a manufacturing technique provides cost management in design and development supports Target costing in Continuous improvement. Target Costing is a process that ensures that the products are designed such that a company can sell them a 
lower cost and still be profitable. Target costing should be treated as a cross functional and integrative approach bridging customers, engineers, designers and accountants and sales persons on one platform. Combination of target costing and KAIZEN provides a base of total life cost management throughout the product life cycle requiring a continuous improvement in Product cost.

M. Suarezbarazza et al, 2011 has carried out the analysis of Kaizen and depicted the tools and techniques used be several authors and proposed three perspectives for understanding Kaizen. Umbrella concepts of Kaizen as management philosophy, a component of TQM and theoretical principle of improvement methodologies and techniques.

D Jurburg et al, 2016 has highlighted the essence of Employees participation in CI activities. The exercise included academicians, practitioners and consultants and a relationship model of 44 elements clustered in 10 factors was developed that could explain the intension of employee to participate in CI activity.

\section{Literature Related to Case Study Related to Kaizen or $\mathbf{C l}$}

Different case studies performed are as discussed below:

John Bessant, David Francis, 1999 discusses the use of "mid-term plans" as a vehicle of policy deployment for three years providing a focus on CI activities at AB industries. The result showed Labour productivity increased by $20 \%$, Reduction in breakdown by $96 \%$, Warranty claims reduced by $50 \%$, Plant efficiency increased by an average of $60 \%$ in span of three years. The results helped in their recovery from losses within a short span of three years after implementation gaining "Zero defects, "Zero accidents" and "Zero breakdown".

Abdulmouti, 2015 focussed on implementation of KAIZEN principles at port installed Option centre at Toyota Saudi Arabia. Kaizen tools including TPS, 5S and the seven muda enabled to understand the system and identify critical areas of transformation. A saving of 5.5 million was achieved by avoiding investing in new facilities. Improvement in efficiency by $26.9 \%$ reducing manpower requirement, Annual improvement by $13 \%$ was also visible.

Sunil Kumar et al, 2017 has brought a novel concept of Lean Kaizen, an improvement technique by continuously elimination non-value added activities through small improvements at an automotive SME industry manufacturing kick starter. Some of the results obtained are reduction in clamping and de-clamping time by $51.72 \%$, Reduction in manpower by $50 \%$, Reduction in production lead time by $69.47 \%$ and value added time by $75.25 \%$, achievement of smooth production and ease in working environment.

Bertes De Jager et al, 2004 has founded the establishment of CI at Kumba, South Africa for CI Capability. The elements identified for establishment of behavioural changes like leadership and managements verbal and non-verbal commitment, use of visual performance, idea system and $5 \mathrm{~S}$ clean up strategy, Understanding individual and team contribution on the bottom line, visual performance measurements, problem solving units, etc. It has been confirmed that CIRCA (Continuous Improvement Research for Competitive Advantage) CI maturity model can be used as a methodology to analyse and enhance CI capability.

Jekelski, Lebrasseur, 1997, proposed the implementation of CI focussing on North American Mining industry. The factors effecting to change culture included employee involvement, corporate presence and customer oriented practical and strategic goals. The results also had insights about the importance of leadership to produces and retain the required in the change process.

Ahuja and Khamba, 2007 have carried out case study in Indian Manufacturing Industry and found that there had been significant improvement in OEE at all production facilities. The benefits achieved through implementation of CI strategies includes OEE improvement: 14-15 per cent, Inventory reduction: 45-58 per cent, increase in Plant output: 22-41 per cent, Reduction in Customer rejection: 50-75 per cent, reduction in accidents: 90-98 per cent, reduction in maintenance cost: 18 45per cent, reduction in defects and rework: 65-80 per cent, reduction in breakdown: 65-78 per cent, 
reduction in energy cost: 8-27 per cent, and total saving by implementation Kaizen themes across the organisation: Rs. 80 million.

Alan J. Fazzari and J. Mosco, 2009 studies the effect of human resource in a 75 year old WI, Inc., a leading designer, manufacturer and marketer of audible, visual and voice-action message product company. With team orientation the outcomes observed were increase in Employee productivity, increase in on-time delivery, cost reduction, increase in sales.

S. Gupta and S. Jain, 2014 has carried out a study related to 5S and Kaizen concept at a small scale industry. The benefits observed consisted of increase in productivity, reduction in failure, reduction in time and distance covered and providing safer environment.

\section{Literature Study of Kaizen/Cl and Embedded Philosophies/Methodologies}

With the pace of globalization, in the last two decades of twentieth century, concentration has been diversion towards quality management strategies and performance improvement dimensions. As the need for continuous improvement on a large scale within an organisation became a major aspect, a number of CI methodologies have developed based on the basic concept of process and quality improvement, reduction of wastes; improve quality simplifying the production lines (N. Bhuiyan \& A Baghel, 2005). The conquest to attain quality, organisations has formalised change programmes or quality initiatives like: Total Quality Management (TQM), Continuous improvement methodologies such as Kaizen, an incremental improvement and breakthrough improvement methodology Business Process Re-Engineering (BPR), Lean Manufacturing (LM), Six Sigma (SS), balanced scorecard etc. and hybrid quality initiatives like Lean Six Sigma (LSS), Lean Kaizen etc. are in the picture. Studying the work of Imai (1886) in the principles of continuous improvement and process orientation can be identified the concepts of Kaizen. The centre of all these Japanese philosophies / methodologies lies the culture of organisation, employee involvement, motivation and education, training needs, recognition etc. within an organisation as observed from the literature.

The phrase CI is associated with a variety of organisational developments including the adoption of "Lean manufacturing" techniques, total quality management (TQM), employee involvement programmes, customer service initiatives and waste reduction campaigns (Sarah Caffyn, 1999). TPM embraces the concept of continuous improvement and total participation by all employees and by all departments (Society of Manufacturing Engineers, 1995).Continuous improvement, also called as Kaizen in Japanese, is a systematic creation and implementation of small-small incremental changes to improve organisation wide performances (J. Bessant et al, 1994), (J. Bessant and S. Caffyn, 1997). CI is a TQM factor (D. Gaddene, Bishnu Sharma, 2009), a concept of TQM hinges on continuous, improvement as the core mission of the upper management (Sushma kumari, 2016), TQM is often regarded as a philosophy that aims to achieve customer satisfaction (S.D. Kalpande et al, 2013), TQM is a continuous process of improvement for individuals, group of people and whole organisation (Gopal K. Kanji, Mike Asher, 1996*), CI should rightfully be regarded as a general development perspective, applicable with or without the context of TQM (Berger, 1996*), Continuous improvement (CI) is an organizational innovation and design principles rooted in Total Quality Management paradigm (P. Lillrank et al, 2001), Objectives like high-quality, cost-efficiency of TQM and CI activities are mechanisms can be accomplished by CI activities (M. Lam et al, 2015), Flexible work and flexible technologies moderated the relationship between TQM and continuous improvement (Janet Marler, 1998) and also Lack of the CI element leads to constraints towards TQM (G.S. Olivera et al, 2017). Lean manufacturing is recognised as a philosophy of CI with increased flexibility aiming improvement in customer service and satisfaction (Alok Mathur et al, 2012). Continuous Improvement is seen as a cornerstone in Lean Thinking (Halvor Holtskog, 2013), The 5S methodology is a very appropriate way to initiate and achieve the process of continuous improvement (Carmen Jaca et al, 2014), Workplace Organisation / 5S, Various housekeeping activities are often used for continuous improvement (Inamdar, Rameez, 2010), Management effort and resources can shift to starting a CI initiative (Åhlström, Par, 1998). 
TQM is a way of life of an organisation committed to customer satisfaction through Continuous improvement, (S. Yosuf and E. Aspinwall, 2000). CI is one of the 8 pillar of Lean Manufacturing (Adian Walsh et al, 2002). Apart from this in the quest of quality improvement implementing an ISO 9000 system solely because customers want it, is a mistake and a small company should aim for continuous improvement and the creation of a quality culture (Yosuf, al, 2002). TPM deals with combined relationship between production and maintenance aiming for Continuous improvement related to quality, operational efficiency and capacity assurance (Chan et al, 2005). Also organisations seeking ISO 9000 with proactive approach, derives significant benefits like quality culture and management responsibility. (Mile Terziovski and Damien Power, 2007). Continuous improvement (CI) programs like Six Sigma do not appear to be easily understood or interpreted by SMEs (Maneesh kumar and J Antoni, 2008). TPM embraces the concept of Continuous improvement and total employees participation by all departments and has emerged into a comprehensive equipment (I.P.S Ahuja and Pankaj kumar, 2008). CI tools have different level of importance in terms of main tools including supplier development, Just in time (JIT), Total involvement (TI), support core work (SCW), TQM, leadership, TPM and customer relationship (J. Singh and H. Singh, 2010). The overlapping of two concepts of Lean manufacturing and Continuous improvement enhances the improvement and the potential may be lost by confusion within them (Julio J. Garcia-Sabater and Juan A. MarinGarcia, 2011). Successful implementation of Kaizen, a philosophy of Continuous improvement can be explored in terms of its organisational design and knowledge management preconditions (Remy Magnier-Watanabe, 2011). Benchmarking is increasing in popularity as a tool for continuous improvement (D. Elmuti, Kathawala, 1999), CI is most practised methodology for Lead Benchmarking (M. Zeinalnezhad et al, 2012), BM is one of the way to find weakness in current practices for CI (Stapley, Sivaloganathan, 1998). Quality function Deployment - Target Costing requires a continuous improvement in product cost, Strategy and employee development is dominant lead performance indicators of continuous improvement (Y. Zengin and Erhan Ada, 2010). Many companies have found the balanced scorecard to be a valuable tool for focusing and sustaining the continuous improvement effort (Robert J. Vokurka, 2004), The importance of the Cost Of Quality (COQ, COPQ) has not been understood as a very important analytical tool to drive continuous improvement (S.N. Teli et al, 2014). Lean-Kaizen concept using VSM to identify hidden continuous improvement opportunities in SMEs (Sunil kumar, 2018).

CI strategies like Failure mode effect analysis Value stream analysis, Process flow mapping, recognition, Cost and Delivery analysis, minor stoppage elimination etc. are significant in harnessing improvements in an organisation (J. Singh and H. Singh, 2017).

Thus Continuous improvement or KAIZEN is embedded in one way or the other with leading philosophies and methodologies with employees' participation, employees involvement, organisation culture, motivation, suggestion, education, learning, leadership, management and training at every stage at its heart

\section{Various Tools of Kaizen or Cl}

Various tools and techniques that has been in use for Kaizen or CI are, PDCA cycle (Sami Al Smadi, 2009), Visual management (Sami Al Smadi, 2009), Elimination of waste (muda), proper communication, cross-functional management, training, 5S, Standardisation, problem solving techniques, Total flow management, Kaizen groups, policy deployment (Hoshin Kanri), Zero defects, Quality circles, improvement suggestion systems, Recognition systems, Total quality control, Total productive maintenance, active training, improvement suggestion systems and just in time (JIT).

\section{CONCLUDING REMARKS}

The purpose of this study is to carry out critical study the art of process of Kaizen or Continuous Improvement (CI), various steps involved in implementation of CI in industries, perceived benefits 
worldwide and especially in India in SME sector along with case studies. A range of databases (1990-2018) are searched to provide a comprehensive listing of Journal articles based on Kaizen or CI. Based on the studies of the articles collected, information related to the implementation of CI in Indian SMEs are studies and the information on a series of variables is collected for future reviewed and classified. This is one part of unique study of review that covers much aspects of Kaizen or CI in worldwide and Indian culture. The current review reveals that the studies on application of Kaizen or CI were mostly related to large organisations, multinational companies and there is a paucity of knowledge when concerned to SMEs globally. However, SMEs are emerging and upgrading themselves to face the competitive world and imitate a part from the large organisations but the hurdles are endless due to many inhibitors. SMEs need to follow a basic comprehensive framework for developing their strategies and quantify their competitiveness in the world. . SMEs are unclear about the advantages (due to lack of knowledge) that one system has over other. Study also reflects the way large companies apply Kaizen/ CI in their departments, units and processes and in organisation as a whole and comes out with a wholesale or incremental solution. The application of Kaizen has been unbounded with its application in other sectors like Services, Medicines, public sector etc. The categorised review in the study will provide better understanding of the present state of the research in this discipline in developing countries like India.

\section{Significant Findings}

The following have been identified by the researchers in the current literature review on Kaizen or CI implementation in Indian and Overseas SMEs:

1. Implementation of Continuous improvement in industries has resulted in several benefits. Apart from that a generalised framework needs to be originated that may be applicable to SMEs.

2. Continuous improvement requires time-consuming training and cultural change (T. Davenport, 1993).

3. Case study based research reported for. The CI / KAIZEN methodology emphasized embedded approach

4. Low wages and the large income gap between labour and management remain a major obstacle to improving worker motivation and involvement in continuous improvement programmes (Justin Barnes et al, 2000)

5. A requirement for adopting a quality culture, implementation of quality initiatives, leads to CI culture based on realistic resource, financial, human and customer needs for the success of the organisation (Sha'ri M. Yusof and Elaine Aspinwall, 2000).

6. The field of knowledge management in small business is of high importance and topics like knowledge implementation, perception and transfer has been researched whereas topics like knowledge identification, storage/retention and utilisation still needs to be further digged out for SMEs (Susanne Durst and Ingi Runar Edvardsson, 2012).

7. CI concept can be effectively employed to realise fundamental improvements of manufacturing performances successfully in competitive environment (J. Singh and H. Singh, 2012).

8. Derailing of CI process always lacks commitment from management that results decrease in value adding over time, competitiveness and profits. (Ole Hoem and Eirin Lodgaard, 2016).

9. CI basic objectives are to allow small group activity, teamwork, encourage leadership, people's involvement, educate with basic statistical quality tools, exposure to problematic situations and develop problem solving techniques and to promote suggestion system scheme whereby decisions can be based on facts (R. Elizondo et al, 2016). 


\section{Gaps in the Current Literature on Kaizen/Continuous Improvement and Agenda for Future Research}

The following gaps have been identified by the Research in the current Literature review on Kaizen or Continuous Improvement.

1. A collaboration of practitioners, academicians, industrialists, educational institutions (S. Lee et al, 2000) and management scholars for proper understanding of the concept of CI, study of various CI tools, easy implementation with less effort in all favourable and adverse conditions for daily course needs to be designed.

2. Requirement for performance measurement on regular basis needs to be inculcated. Auditing needs to be regularly carried out and the outcomes needs to be over ruled to sustain the culture.

3. A necessity of framework for implementation of CI particularly for SMEs pertaining to different segments is a basic requirement.

4. Implementation and sustainability of CI or Kaizen rests with the employees, their involvement at various stages. Individual base and team base suggestion scheme needs to be formulated and correct implementation of suggestion scheme along with recognition and reward is a need of an hour.

5. The main resistance is the culture and the employee involvement and these are the primary goals that need to be identified and removed.

6. CI is still an untapped resource (J Bessant et al, 1993). CI implementation is generally carried out in overseas industries but very few cases have been observed in industries in developing country like India where SMEs are found in large numbers.

7. The concept of Kaizen or CI has been in use since last three decades in various countries of the world, but the research outcomes from Indian SMEs have been very few. This translates that there has been a lot of work to be carried out in this direction in a developing country like India.

8. SMEs are reliant ton their own internal learning resources, which in many cases are poorly understood and utilised (S. Caffyn and A. Grantham, 2003).

9. Exploratory study is required to distinguish CI from other improvement activities (Jeff Readmen and J. Bessant, 2007).

\section{CONCLUSION}

The literature review reveals that studies have been carried out on implementation and application of Continuous improvement methodology has been limited in Indian SMEs, but the same have been carried out since last three decades in European and American continents. As rightly said, Kaizen has abundant opportunities for future Research (R. Cheser, 1998), also the same needs to be understood and studies pertaining on how Large organisations apply this concept to their units, processes and departments and to the organisation as a whole and discover the benefits.

The application of the concept needs to be started with the different tools and techniques so as to obtain perceived benefits. To achieve the goals companies needs to select tools that suit the people within the organisation (P Hyland et al, 2000). Continuous improvement strategies includes 5S, total cost management, preventive maintenance, Quality function deployment, suggestion system etc. can be used to achieve small incremental changes in manufacturing system processes (J. Singh and H. Singh, 2019).

The study has following limitation:

a. Study has been carried on various sophisticated CI methodologies like Lean, Six Sigma, LSS, etc. and its usage has been fruitful to achieve CI but no specific framework or approach has been mentioned for observed. 
b. Limited strategies have been implemented to ascertain the benefits occurred after CI implementation.

c. The study is limited to inclusion of additional issues related to understanding of CI, implementation of CI, generalised framework generation and much more that leads to achievement of laid goals and success of CI in SMEs across the country.

Scope for future work:

The review needs to be elaborated by determining the stages of difficulties in implementation of CI in SMEs.

Generation of a framework suitable for the said manufacturing SME and ascertaining the benefits occurred and also validation of the framework. 


\section{REFERENCES}

Abdulmouti, H. (2015). The role of Kaizen (continuous improvement) in improving companies' performance: A case study. IEOM 2015 - 5th International Conference on Industrial Engineering and Operations Management, Proceeding.

Ahlstrom, P. (1997). Sequences in the Process of Adopting Lean Production. Stockholm School of Economics.

Ahuja, I. P. S., \& Kumar, P. (2009). A case study of total productive maintenance implementation at precision tube mills. Journal of Quality in Maintenance Engineering, 15(3), 241-258. doi:10.1108/13552510910983198

Antoni, M., Nilsson-Witell, L., \& Dahlgaard, J. J. (2005). Inter-project improvement in product development. International Journal of Quality \& Reliability Management, 22(9), 876-893. doi:10.1108/02656710510625194

Aoki, K. (2008). Transferring Japanese kaizen activities to overseas plants in China. International Journal of Operations \& Production Management, 28(6), 518-539. doi:10.1108/01443570810875340

Bala Subrahmanya, M. H. (2009). Nature and strategy of product innovations in SMEs: A case study-based comparative perspective of Japan and India. Innovation: Management. Policy \& Practice, 11(1), $104-113$. doi:10.5172/impp.453.11.1.104

Barnes, J., Bessant, J., Dunne, N., \& Morris, M. (2001). Developing manufacturing competitiveness within South African industry: The role of middle management. Technovation, 21(5), 293-309. doi:10.1016/S01664972(00)00047-X

Berger, A. (1996). Perspectives on manufacturing development - discontinuous change and continuous improvement ( $\mathrm{PhD}$ thesis). Chalmers University of Technology, Go“teborg.

Berger, A. (1997). Continuous improvement and kaizen: Standardization and organizational designs. Integrated Manufacturing Systems, 8(2), 110-117. doi:10.1108/09576069710165792

Bessant, J. (2003). Developing Continuous Improvement Capability. International Journal of Innovation Management, 2(4), 409-429. doi:10.1142/S1363919698000183

Bessant, J., Burnell, J., Harding, R., \& Webb, S. (1993). Continuous improvement in British manufacturing. Technovation, 13(4), 241-254. doi:10.1016/0166-4972(93)90021-M

Bessant, J., \& Caffyn, S. (1997). High-involvement innovation through continuous improvement. International Journal of Technology Management, 14(1), 7-27. doi:10.1504/IJTM.1997.001705

Bessant, J., Caffyn, S., \& Gallagher, M. (2001). Evolutionary model of continuous improvement behaviour. Technovation, 21(2), 67-77. doi:10.1016/S0166-4972(00)00023-7

Bessant, J., Caffyn, S., Gilbert, J., Harding, R., \& Webb, S. (1994). Rediscovering continuous improvement. Technovation, 14(1), 17-29. doi:10.1016/0166-4972(94)90067-1

Bhuiyan, N., \& Baghel, A. (2005). An overview of continuous improvement: From the past to the present. Management Decision, 43(5), 761-771. doi:10.1108/00251740510597761

Boer, H., Berger, A., Chapman, R., \& Gertsen, F. (2000). CI Changes: From Suggestion Box to Organizational Learning. Continuous improvement in Europe and Australia. Ashgate.

Boer, H., \& Gertsen, F. (2003). From continuous improvement to continuous innovation : A (retro)(per)spective. International Journal of Technology Management, 26(8), 805-827. doi:10.1504/IJTM.2003.003391

Briefs, S., \& Operations, I. N. (1999). Development of a continuous improvement self-assessment tool. International Journal of Operations \& Production Management, 19(11), 1138-1153. doi:10.1108/01443579910291050

Carnerud, D., Jaca, C., \& Bäckström, I. (2018). Kaizen and continuous improvement - trends and patterns over 30 years. The TQM Journal, 30(4), 371-390. doi:10.1108/TQM-03-2018-0037

Centre, T. F. (2003). Fostering Continuous Improvement within new product development processes Sarah Caffyn and Andrew Grantham. Technology (Elmsford, N.Y.), 26(8). 
Chan, F. T. S., Lau, H. C. W., Ip, R. W. L., Chan, H. K., \& Kong, S. (2005). Implementation of total productive maintenance: A case study. International Journal of Production Economics, 95(1), 71-94. doi:10.1016/j. ijpe.2003.10.021

Cheser, R., \& Tanner, C. (1993). Critikon Declares War on Waste, Launches Kaizen Drive. Target.

Cheser, R. N. (2008). the Effect of Japanese Kaizen on Employee Motivation in U.S. Manufacturing. The International Journal of Organizational Analysis, 6(3), 197-217. doi:10.1108/eb028884

Choi, T. (1995). Conceptualizing continuous improvement: Implications for organizational change. Omega, 23(6), 607-624. doi:10.1016/0305-0483(95)00041-0

Corso, M., Giacobbe, A., Martini, A., \& Pellegrini, L. (2007). Tools and abilities for continuous improvement: What are the drivers of performance? International Journal of Technology Management, 37(3/4), 348. doi:10.1504/IJTM.2007.012268

Davenport, T. H. (1993). Need radical innovation and continuous improvement? Integrate process reengineering and TQM. Planning Review, 21(3), 6-12. doi:10.1108/eb054413

Durst, S., \& Edvardsson, I. R. (2012). Knowledge management in SMEs: A literature review. Journal of Knowledge Management, 16(6), 879-903. doi:10.1108/13673271211276173

Elmuti, D., \& Kathawala, Y. (1997). An overview of benchmarking process: A tool for continuous improvement and competitive advantage. Benchmarking for Quality Management \& Technology, 4(4), $229-243$. doi:10.1108/14635779710195087

Farris, J. A., Van Aken, E. M., Doolen, T. L., \& Worley, J. (2008). Learning from less successful kaizen events: A case study. EMJ -. Engineering Management Journal, 20(3), 10-20. doi:10.1080/10429247.2008.11431772

Gadenne, D., \& Sharma, B. (2009). An investigation of the hard and soft quality management factors of Australian SMEs and their association with firm performance. International Journal of Quality \& Reliability Management, 26(9), 865-880. doi:10.1108/02656710910995064

Gondhalekar, S., Babu, A. S., \& Godrej, N. B. (1995). Towards TQM using kaizen process dynamics: A case study. International Journal of Quality \& Reliability Management, 12(9), 192-209. doi:10.1108/02656719510101286

Gupta, S., \& Jain, S. K. (2014). The 5S and kaizen concept for overall improvement of the organisation : A case study Shaman Gupta Sanjiv Kumar Jain *. International Journal of Lean Enterprise Research, 1(1), 22-40. doi:10.1504/IJLER.2014.062280

Hoem, O., \& Lodgaard, E. (2016). Model for Supporting Lasting Managerial Efforts in Continuous Improvement: A Case Study in Product Engineering. Procedia CIRP, 50, 38-43. doi:10.1016/j.procir.2016.05.020

Holtskog, H. (2013). Continuous improvement beyond the lean understanding. Procedia CIRP, 7, $575-579$. doi:10.1016/j.procir.2013.06.035

Hyland, P. (2000). A comparison of Australian firms and their use of continuous improvement tools Innovation and strategy. The TQM Magazine, 12(2), 117-124.

Hyland, P., Sloan, T., \& Barnett, D. (1998). Changing culture through empowerment. Journal of European Industrial Training, 22(9), 349-353. doi:10.1108/03090599810240983

Imai, M. (1986). Kaizen. The key to Japan's competitive success. Random House.

Imai, M. (1997). Gemba Kaizen: A Common sense. Low-Cost Approach to Management, McGraw Hill Publication.

Imai, M. (1989). Kaizen, la clé de la compétitivité japonaise. Eyrolles.

Jaca, C. (2014). Learning 5S principles from Japanese best practitioners: Case studies of five manufacturing companies. International Journal of Production Research, 52(15), 4574-4586.

Imai, M., \& Heymans, B. (1999). Gemba Kaizen. Berrett-Koehler Communications.

Jager, B. (2004). Enabling continuous improvement: A case study of implementation. Journal of Manufacturing Technology Management, 15(4), 315-324. doi:10.1108/17410380410535017 
Jakelski, D., \& LeBrasseur, R. (1997). Implementing Continuous Improvement in the North American Mining Industry. Technological Forecasting and Social Change, 55(2), 165-177. doi:10.1016/S0040-1625(96)00186-2

John Bessant, D. F. (1999). Developing Strategic continuous improvement capability. Emerald, 19(11), 1106-1119.

Jørgensen, F., Boer, H., \& Laugen, B. T. (2006). CI Implementation: An Empirical Test of the CI Maturity Model. Creativity and Innovation Management, 15(4), 328-337.

Juergensen, T. (2000). Continuous improvement: Mindsets, capability, process, tools and results. The Juergensen Consulting Group.

Jurburg, D. (2016). What motivates employees to participate in continuous improvement activities? Total Quality Management \& Business Excellence, 3363(March), 1-20.

Jurburg, D., Viles, E., Jaca, C., \& Tanco, M. (2015). Why are companies still struggling to reach higher continuous improvement maturity levels? Empirical evidence from high performance companies. The TQM Journal, 27(3), 316-327. doi:10.1108/TQM-11-2013-0123

Kalpande, S.D., Gupta, R.C. \& Dandekar, M.D. (2013). Identification of important factors for implementation of TQM in Indian SMEs in context of Vidarbha and Khandesh region. International Journal of Management and Enterprise Development, 12(4/5/6), 411.

Karkoszka, T., \& Honorowicz, J. (2009). Kaizen philosophy a manner of continuous improvement of processes and products Industrial management and organisation. Journal of Achievements in Materials and Manufacturing Engineering, 352(2), 197-203.

Khan, Z., Bali, R. K., \& Wickramasinghe, N. (2007). Developing a BPI framework and PAM for SMEs. Industrial Management \& Data Systems, 107(3), 345-360. doi:10.1108/02635570710734262

Kulkarni, S. (2005). Graph theory and matrix approach for performance evaluation of TQM in Indian industries. The TQM Magazine, 17(6), 509-526. doi:10.1108/09544780510627615

Kumar, M., \& Antony, J. (2008). Comparing the quality management practices in UK SMEs. Industrial Management \& Data Systems, 108(9), 1153-1166. doi:10.1108/02635570810914865

Kumar, S., Dhingra, A. K., \& Singh, B. (2018). Process improvement through Lean-Kaizen using value stream map: A case study in India. International Journal of Advanced Manufacturing Technology, 96(5-8), 2687-2698. doi:10.1007/s00170-018-1684-8

Kumar, S., \& Harms, R. (2004). Improving business processes for increased operational efficiency: A case study. Journal of Manufacturing Technology Management, 15(7), 662-674. doi:10.1108/17410380410555907

Leandro Elizondo, R., Grabot, B., \& Houe Ngouna, R. (2016). Beyond Productivity and Continuous Improvement: Fundamentals required for Lean Complex transformation Unpublished. IFAC-PapersOnLine, 49(12), 467-472. doi:10.1016/j.ifacol.2016.07.655

Lee, B. S. S., Dugger, J. C., \& Chen, J. C. (2000). Kaizen : An Essential Tool for Inclusion in Industrial Technology Curricula. Journal of Information Technology, 16(1), 1-7.

Lillrank, P., \& Kano, N. (1989). Continuous improvement quality control circles in Japanese industry. University of Michigan. doi:10.3998/mpub.18699

Lillrank, P., Shani, A. B., \& Lindberg, P. (2001). Continuous improvement: Exploring alternative organizational designs. Total Quality Management, 12(1), 41-55. doi:10.1080/09544120020010084

Locke, E. A., \& Jain, V. K. (2008). Organizational Learning and Continuous Improvement. The International Journal of Organizational Analysis, 3(1), 45-68. doi:10.1108/eb028823

Magnier-Watanabe, R. (2011). Getting ready for kaizen: Organizational and knowledge management enablers. Vine, 41(4), 428-448. doi:10.1108/03055721111188520

Majumdar, J., \& Manohar, B. (2016). Why Indian manufacturing SMEs are still reluctant in adopting total quality management Jyoti Prakas Majumdar* and. International Journal of Productivity and Quality Management, 17(1), 16-35. doi:10.1504/IJPQM.2016.073273 
Marler, J. H. (1998). The effect of TOM training, flexible work, and flexible technology on continuous improvement. Journal of Quality Management, 3(2), 241-264. doi:10.1016/S1084-8568(99)80116-3

Mathur, A., Mittal, M. L., \& Dangayach, G. S. (2012). Improving productivity in Indian SMEs. Production Planning and Control, 23(10-11), 754-768. doi:10.1080/09537287.2011.642150

McAdam, R., Stevenson, P., \& Armstrong, G. (2000). Innovative change management in SMEs: Beyond continuous improvement. Logistics Information Management, 13(3), 138-149. doi:10.1108/09576050010326538

Mulhaney, A., Sheehan, J., \& Hughes, J. (2004). Using ISO9000 to drive continual improvement in a SME. The TQM Magazine, 16(5), 325-330. doi:10.1108/09544780410551250

Oliveira, G. S. (2017). Investigation of TQM implementation: Empirical study in Brazilian ISO 9001-registered SMEs. Total Quality Management \& Business Excellence, 3363(May), 1-19.

Palmer, V. S. (2001). Inventory Management Kaizen Anatomy of a Kaizen Week. Academic Press.

Paul Brunet, A., \& New, S. (2003). Kaizen in Japan: An empirical study. International Journal of Operations \& Production Management, 23(12), 1426-1446. doi:10.1108/01443570310506704

Radharamanan, R., Godoy, L. P., \& Watanabe, K. I. (2003). Quality and productivity improvement in a custommade furniture industry using Kaizen. Computers \& Industrial Engineering, 31(1-2), 471-474.

Rameez, H., \& Inamdar, K. (2010). Areas of lean manufacturing for productivity improvement in a manufacturing unit. World Academy of Science. E (Norwalk, Conn.), 45(9), 584-587.

Readman, J., \& Bessant, J. (2007). What challenges lie ahead for improvement programmes in the UK? Lessons from the CINet Continuous Improvement Survey 2003. International Journal of Technology Management, 37(3-4), 290-305. doi:10.1504/IJTM.2007.012264

Sabater, J. J. G., \& Garcia, J. A. M. (2011). Can we still talk about continuous improvement? Rethinking enablers and inhibitors for successful implementation. International Journal of Technology Management, 55(1/2), 28. doi:10.1504/IJTM.2011.041678

Sanchez, L., \& Blanco, B. (2014). Three decades of continuous improvement. Total Quality Management \& Business Excellence, 25(9-10), 986-1001. doi:10.1080/14783363.2013.856547

Schonberger. (1986). World Class Manufacturing: The Lessons of Simplicity Applied. The Free Press.

Singh, J., \& Singh, H. (2015). Continuous improvement philosophy-literature review and directions. Academic Press.

Singh, J., \& Singh, H. (2010). Assessment of continuous improvement approach in SMEs of Northern India. International Journal of Productivity and Quality Management, 5(3), 252-268. doi:10.1504/IJPQM.2010.032068

Al Smadi, S. (2009). Kaizen strategy and the drive for competitiveness: Challenges and opportunities. Competitiveness Review, 19(3), 203-211. doi:10.1108/10595420910962070

Mole, V., \& Elliot, D. (1987). Enterprising Innovation: An Alternative Approach. Belhaven Pr.

Singh, J., \& Singh, H. (2012). Continuous improvement approach: State-of-art review and future implications. International Journal of Lean Six Sigma, 3(2), 88-111. doi:10.1108/20401461211243694

Singh, K., \& Ahuja, I. S. (2015). An evaluation of transfusion of TQM-TPM implementation initiative in an Indian manufacturing industry. Journal of Quality in Maintenance Engineering, 21(2), 134-153. doi:10.1108/ JQME-04-2013-0017

Sraun, J. S., \& Singh, H. (2017). Continuous improvement strategies across manufacturing SMEs of Northern India-an empirical investigation. International Journal of Lean Six Sigma, 8(2), IJLSS-05-2016-0019. doi:10.1108/IJLSS-05-2016-0019

Stapley, M. \& Sivaloganathan, S., (1998). A methodology for manufacturing process benchmarking in metal removal industry. Academic Press.

Suárez-Barraza, M. F., \& Lingham, T. (2017). Kaizen within Kaizen Teams: Continuous and Process Improvements in a Spanish municipality. Asian Journal on Quality, 9(1), 1-21. doi:10.1108/15982688200800001 
Suárez-Barraza, M. F., Ramis-Pujol, J., \& Kerbache, L. (2011). Thoughts on kaizen and its evolution: Three different perspectives and guiding principles. International Journal of Lean Six Sigma, 2(4), 288-308. doi:10.1108/20401461111189407

Swaminathan, A., \& Sudhakar, S. (2017). Somewhat pairwise fuzzy pre continuous mappings. Thai Journal of Mathematics, 15(2), 359-365.

Teli, S.N. (2014). Impact of poor quality cost in automobile industry. Academic Press.

Terziovski, M., \& Power, D. (2007). Increasing ISO 9000 certification benefits: A continuous improvement approach. International Journal of Quality \& Reliability Management, 24(2), 141-163. doi:10.1108/02656710710722266

Tुîţu, A. M., Răulea, A. S., \& Ţîțu, Ş. (2015). Innovation - A Challenge for the 21st Century Managers. Procedia Economics and Finance, 27(15), 126-135. doi:10.1016/S2212-5671(15)00981-8

Vokurka, R. J. (2004). Operationalising the balanced scorecard using the Malcolm Baldrige Criteria for Performance Excellence (MBCPE). International Journal of Management and Enterprise Development, 1(3), 1-1. doi:10.1504/IJMED.2004.004521

Walsh, A., Hughes, H., \& Maddox, D. P. (2002). Total quality management continuous improvement: Is the philosophy a reality? Journal of European Industrial Training, 26(6), 299-307. doi:10.1108/03090590210431274

Wittenberg, G. (1994). Kaizen - The many ways of getting better. Assembly Automation, 14(4), 12-17. doi:10.1108/EUM0000000004213

Yusof, S. M., \& Aspinwall, E. (2000). TQM implementation issues: Review and case study. International Journal of Operations \& Production Management, 20(6), 634-655. doi:10.1108/01443570010321595

Zeinalnezhad, M., Mukhtar, M., \& Sahran, S. (2014). An investigation of lead benchmarking implementation: A comparison of small/medium enterprises and large companies. Benchmarking, 21(1), 121-145. doi:10.1108/ BIJ-09-2011-0074

Zengin, Y., \& Ada, E. (2010). Cost management through product design: Target costing approach. International Journal of Production Research, 48(19), 5593-5611. doi:10.1080/00207540903130876

Mr. Pritesh R. Patel is a last year PhD student and works as Assistant Professor in Mechanical Engineering. His $P h D$ research area deals with Continuous improvements in SMEs. He is having around 8 years experience in Industrial environment at various levels in different industries and 9 years of teaching experience. He has guided many UG projects. His area of research includes Lean Manufacturing, Cost of Quality, TQM and Advanced Manufacturing processes.

Darshak Desai (PhD), Head of Mechanical Engineering, is having 9 years of hard core industrial experienced at various levels and 20 years of teaching experience. He has published more than 60 research papers at National and International levels. He is also invited reviewer and editorial board member at few reputed International Journals. Dr. Desai has authored 7 textbooks for diploma and degree engineering students. He is a certified Lean Six Sigma Black Belt and his area of research is Quality Engineering, especially, Six Sigma. He has guided many UG and PG projects. One scholar has completed Ph D under him and currently he is guiding 4 Ph D scholars. His areas of research and interests also includes Cost of Quality Systems and TQM, Production and Operations Management, Industrial Engineering, and Supply Chain Management. 